\title{
Clarifying the Use of Benzylidene Protecting Group for D-(+)-Ribono-1,4-Lactone, an Essential Building Block in the Synthesis of $C$-Nucleosides
}

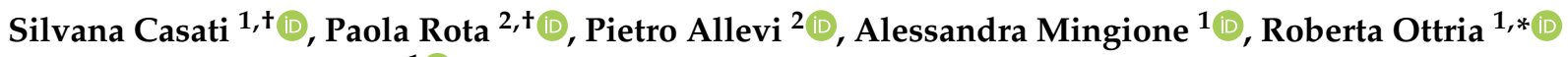 \\ and Pierangela Ciuffreda ${ }^{1}$ D \\ 1 Dipartimento di Scienze Biomediche e Cliniche "Luigi Sacco", Università degli Studi di Milano, \\ Via G.B. Grassi 74, 20157 Milano, Italy; silvana.casati@unimi.it (S.C.); alessandra.mingione@unimi.it (A.M.); \\ pierangela.ciuffreda@unimi.it (P.C.) \\ 2 Dipartimento di Scienze Biomediche, Chirurgiche e Odontoiatriche, Università degli Studi di Milano, \\ Via Saldini 50, 20133 Milano, Italy; paola.rota@unimi.it (P.R.); pietro.allevi@unimi.it (P.A.) \\ * Correspondence: roberta.ottria@unimi.it; Tel.: +39-02-5031-9693 \\ $+\quad$ These authors contributed equally to this work.
}

check for updates

Citation: Casati, S.; Rota, P.; Allevi, P.; Mingione, A.; Ottria, R.; Ciuffreda, P. Clarifying the Use of Benzylidene

Protecting Group for

D-(+)-Ribono-1,4-Lactone, an Essential Building Block in the Synthesis of C-Nucleosides. Molecules 2021, 26, 6447. https://doi.org/ $10.3390 /$ molecules 26216447

Academic Editor: Baoan Song

Received: 21 September 2021

Accepted: 23 October 2021

Published: 26 October 2021

Publisher's Note: MDPI stays neutral with regard to jurisdictional claims in published maps and institutional affiliations.

Copyright: (C) 2021 by the authors Licensee MDPI, Basel, Switzerland. This article is an open access article distributed under the terms and conditions of the Creative Commons Attribution (CC BY) license (https:// creativecommons.org/licenses/by/ $4.0 /)$.

\begin{abstract}
In the last two years, nucleosides analogues, a class of well-established bioactive compounds, have been the subject of renewed interest from the scientific community thanks to their antiviral activity. The COVID-19 global pandemic, indeed, spread light on the antiviral drug Remdesivir, an adenine $C$-nucleoside analogue. This new attention of the medical community on Remdesivir prompts the medicinal chemists to investigate once again $C$-nucleosides. One of the essential building blocks to synthetize these compounds is the D-(+)-ribono-1,4-lactone, but some mechanistic aspects linked to the use of different carbohydrate protecting groups remain unclear. Here, we present our investigations on the use of benzylidene as a ribonolactone protecting group useful in the synthesis of C-purine nucleosides analogues. A detailed 1D and 2D NMR structural study of the obtained compounds under different reaction conditions is presented. In addition, a molecular modeling study at the B3LYP /6-31G* level of theory with the SM8 solvation model for $\mathrm{CHCl}_{3}$ and DMSO to support the obtained results is used. This study allows for clarifying mechanistic aspects as the side reactions and structural rearrangements liked to the use of the benzylidene protecting group.
\end{abstract}

Keywords: ribono-1,4-lactone; 1-C-substituted nucleosides; protecting groups; cyclic acetals

\section{Introduction}

Nucleosides play key roles in biological processes such as the preservation, replication, and transcription of genetic information, energy storage, transmission signaling, and metabolism regulation. Nucleoside analogues can be used as nucleic acid metabolism inhibitors to interfere with viral replication and cancer cell growth, showing remarkable antiviral and antitumor effects. Consequently, the synthesis of new molecules of this class with original substitution patterns remains a challenge for medicinal chemists [1-3].

In the last year, the Food and Drug Administration (FDA) issued an Emergency Use Authorization (EUA) for Remdesivir (1, Figure 1), a 1'-cyano-substituted adenine C-nucleoside ribose analogue, to the treatment of Corona Virus Disease 2019 (COVID-19) patients, so nucleoside-derived drugs have once again received widespread attention in the scientific community [4-8].

While natural and synthetic $N$-nucleosides are vulnerable to enzymatic and acidcatalyzed hydrolysis of the nucleosidic bond, their $C$-analogues are much more stable [9]. A key challenge in the preparation of this family of compounds is the coupling of the ribose with the base moieties. The different syntheses of Remdesivir (1) analogues reported in literature [10-12] involve the use of D-(+)-ribono-1,4-lactone (2). 


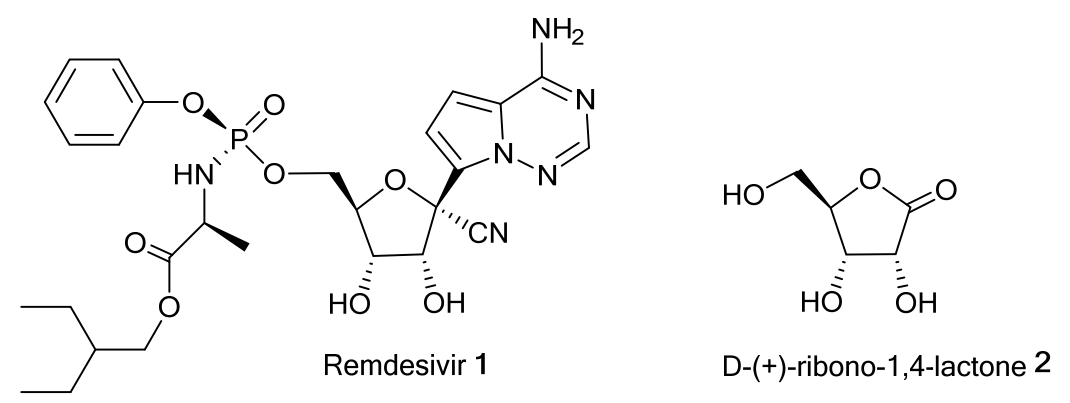

Figure 1. Chemical structures of the antiviral drug Remdesivir 1 and the D-(+)-ribono-1,4-lactone 2 building block.

Lactone $\mathbf{2}$ is a natural compound present in the leaves of Listea japonica and, therefore, is commercially available from renewable sources. Because of its high functionalization with contiguous chiral centers, it has been widely used as a versatile chiral building block for the construction of a variety of natural products $[13,14]$ as well as compounds relevant to medicinal chemistry and/or chemical biology, including nucleotides and C-ribonucleosides as antiviral agents $[15,16]$.

The appropriate protection and deprotection of the three hydroxyl groups of the D-(+)-ribono-1,4-lactone (2) is a fundamental aspect to be considered in the synthesis of nucleoside derivatives. Not always does the selection of a versatile and smart protecting group lead to an optimized synthetic route, sometimes it can indeed affect the result of the whole synthetic procedure, as demonstrated by our past studies $[17,18]$. In the synthesis of 1'-C-methyl-adenosines, indeed, the D-(+)-ribono-1,4-lactone (2) was selected as starting material to obtain compound 4 , via isopropylidene protected intermediate 3 . Then, the formation of the $\mathrm{N}$-glicosidic bond between 4 and chloropurine 5 gave compound $\mathbf{6}$, from which differently substituted $C$-nucleosides 7 were synthesized (Scheme 1 ). All attempts of deprotection, to obtain the corresponding 8 , using several of the different methods reported in the literature [19], resulted in $N$-ribosidic bond cleavage.

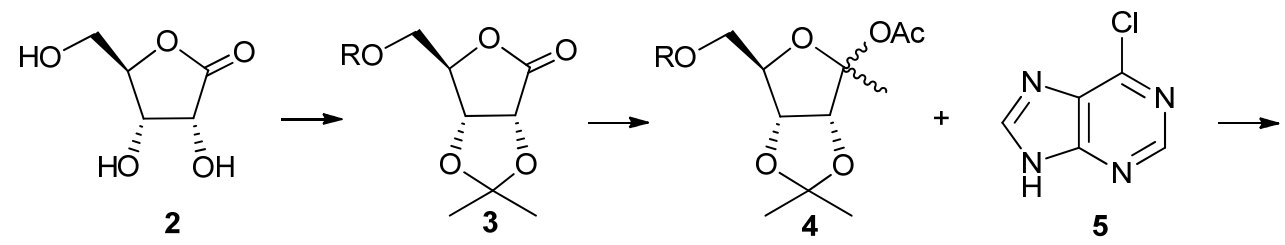<smiles>[R20]C[C@H]1O[C@](C)(n2cnc3c(Cl)ncnc32)[C@H]2OC(C)(C)O[C@@H]21</smiles>

Scheme 1. Planned pathway to achieve the $1^{\prime} C$-substituted nucleosides analogue 8.

The use of isopropylidene as selective protection of the two neighboring hydroxyl groups in the ribonolactone 2 allows for the protection and functionalization at 5 position, fundamental for medicinal chemists to obtain libraries of potentially active nucleoside analogues. Unfortunately, it is limited to the synthesis of pyrimidine analogues, as in the purine series the acetonide deprotection is unsuccessful, probably due to the greater sensitivity of these substrates to the required acidic conditions. 
The overcoming of this severe drawback remains a key goal for medicinal chemistry of purine derivatives, especially for adenosine analogues that are a relevant family of compounds with important biological and pharmacological applications [20-23]. An alternative route for the protection of the two neighboring hydroxyl groups can be the use of the benzylidene instead of the isopropylidene protecting group. Even in this case, however, unexpected reactions or structure rearrangements of the ring can occur, leading to confusing outcomes.

In this study, we report our investigation on the different reactivity of ribonolactone 2 toward either benzaldehyde or benzaldehyde dimethyl acetal in the presence of protic or Lewis acids as catalysts. The detailed study of chemical structures of the isolated compounds was performed by spectroscopic analyses, by 1D and 2D-NMR, and allowed to clarify some aspects of the use of this protecting group.

\section{Results and Discussion}

\subsection{Syntheses and NMR Studies}

Cyclic acetals and ketals [19], the most well-established and frequently used protective groups in carbohydrate chemistry synthetic strategies, have been thoroughly reviewed $[24,25]$. Although there are many studies published on this subject [24,26-28], it is not always possible to predict which isomer will be obtained under acetalization conditions. To understand and rationalize some observed results, including ring rearrangements, a detailed investigation of the reactions of D-(+)-ribono-1,4-lactone (2) with benzaldehyde or benzaldehyde dimethyl acetal under different reaction conditions was carried out.

If we consider the studies of Han et al. [29,30], the benzylidenation of ribonolactone 2 in aqueous and thermodynamically controlled conditions can lead to five possible types of lactones passing through the ring-opening in compound 9, the 3,5- and 2,3-benzylidene1,4-lactones 10 and 11, respectively, the 3,4-2,3- and 2,4-benzylidene-1,5-lactones 12, 13 and 14, respectively, each of which can exist as a pair of acetal epimers (Scheme 2).

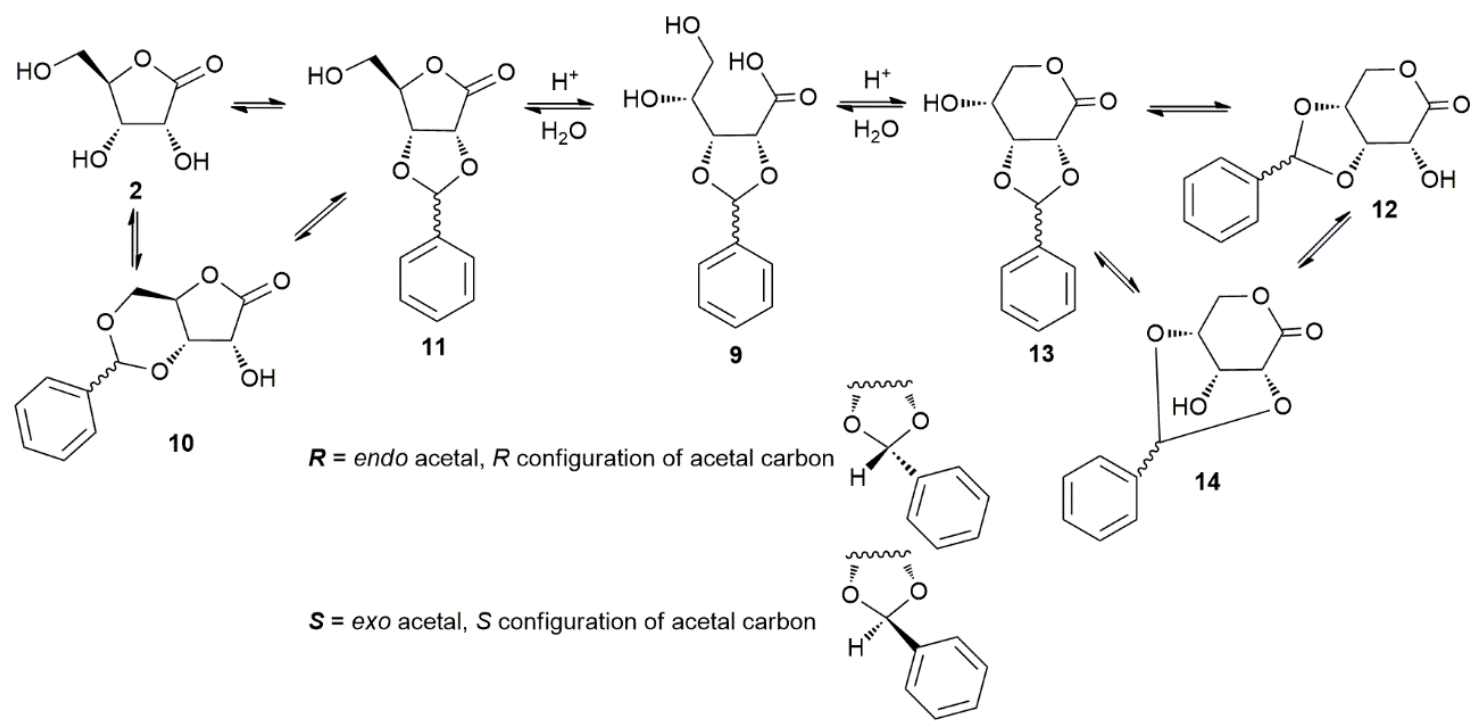

Scheme 2. Possible products in the equilibrium mixture of the acetalization of ribonolactone 2: two ribofuranoside acetals (10 and 11) and three ribopyranoside acetals (12-14) as epimeric couples at the acetalic carbon.

Depending on the substrate, the carbonyl compound used, and different reaction conditions, it is often possible to obtain only some of the many possible isomeric products due to the ring expansion and/or rearrangements involving acetal migration [31]. Moreover, the structural similarity of compounds 10-12, combined with their easy interconversion, has led to several mistakes into structures and NMR signals assignments. 
For instance, the 3,5-O-benzylidene structure 10 was suggested by Zinner et al. [32] in preference to the 2,3-acetal derivative 12, for the product obtained from the reaction of D-(+)-ribono-1,4-lactone (2) with benzaldehyde in acidic conditions.

The correct structure was afterwards unequivocally established as 3,4-O-benzylideneD-(+)-ribono-1,5-lactone (12) by $X$-ray diffraction analysis of its $O$-acetyl derivative [33]. Furthermore, 3,5-acetal derivative 10 structure was excluded [33], since no other genuine 3,5-cyclic acetals of furanoid derivatives of ribose, formed under equilibrating conditions, have been described. Moreover, molecular models suggested to the authors that a 3,5-acetal such as 10 would be more highly strained than the corresponding 2,3-acetal 11.

In our studies on the synthetic transformations of nucleosides, the synthesis of selectively acylated acetals of D-(+)-ribono-1,4-lactone (2) was required. Based on the above and keeping in mind that because of equilibrium reactions the products could be of various nature, a detailed NMR investigation on the structures of the compounds obtained by the benzylidene protection of 1,4-lactone 2 under different conditions was performed and a detailed description is herein reported. Indeed, the correct identification of the compounds obtained from acetalization, reached only by an adequate NMR study and structural assignment of the spectra, is of fundamental importance to ensure the correct furanosidic structure of the ribose moiety in the final products.

Treatment of D-(+)-ribono-1,4-lactone (2) with benzaldehyde and aqueous concentrated $\mathrm{HCl}$ at room temperature overnight afforded, after $\mathrm{Et}_{2} \mathrm{O}$ addition, the 3,4-O- $(R)$ benzylidene-D-ribono-1,4-lactone (12R, endo-phenyl) in high yield (81\%). The insolubility of $12 R$ together with its formation under equilibrating conditions likely enables its isolation as a single diastereoisomer. Otherwise, when anhydrous $\mathrm{ZnCl}_{2}$ was used as a catalyst in 1,2dimethoxyethane (DME), a diastereomeric mixture of 2,3-O-(R)-benzylidene derivative $\mathbf{1 1} R$ (55\% yield) and its $(S)$-isomer $\mathbf{1 1 S}$ (12\% yield) was isolated. Compound $\mathbf{1 1} \boldsymbol{R}$ was the major product, as previously reported [33]. Treatment of 2 with benzaldehyde dimethyl acetal and a catalytic amount of anhydrous $\mathrm{SnCl}_{2}$ in $\mathrm{DME}$ yielded compounds $\mathbf{1 1 R}$ (58\% yield) and $\mathbf{1 1 S}$ (7\% yield). The formation of 12 was not observed under non-aqueous reaction conditions, according to the literature [30] (Scheme 3).

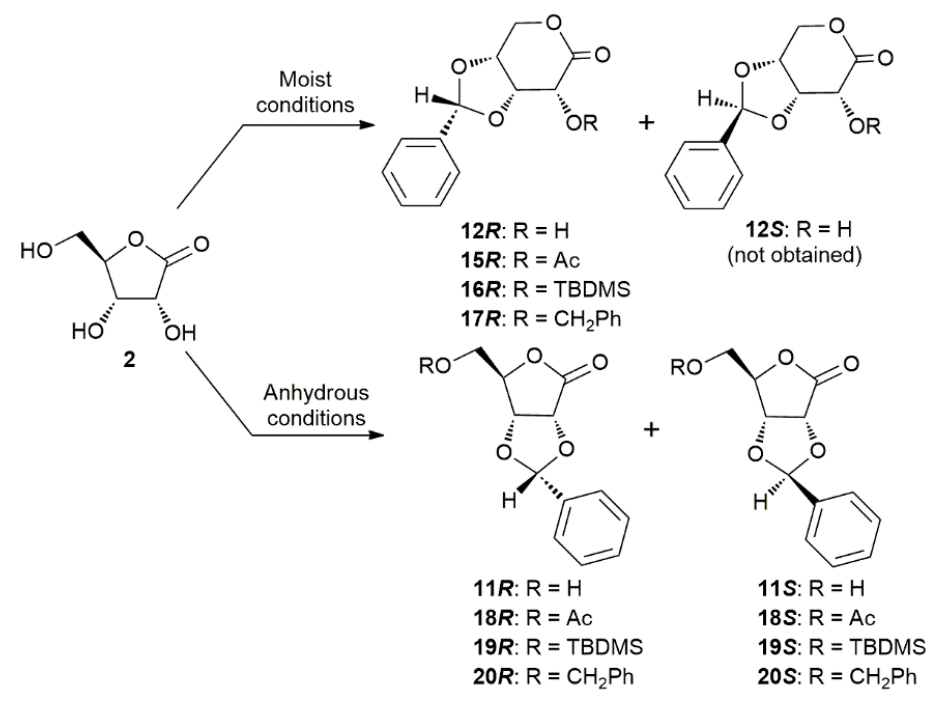

Scheme 3. Products of benzylidenation in thermodynamic controlled moist and anhydrous conditions and corresponding derivatives.

The obtained compounds were additionally protected at position 5 for $\mathbf{1 1 R}$ and $\mathbf{1 1 S}$ or at position 2 for $12 R$ as acetate $(18 R, 18 S$, and 15R), $t$-butyldimethylsilyl $(19 R, 19 S$, and $16 R)$, and benzyl $(20 R, 20 S$, and $17 R)$ groups. The acetylation and the silylation were performed using the classical reaction conditions. Also, under conventional benzylation conditions ( $\mathrm{NaH}$ and benzyl bromide as reagents) [20-23], the compounds $\mathbf{1 1 R}$ and $\mathbf{1 1 S}$ afforded, as expected, the ribofuranoside benzyl derivatives $20 R$ and $20 S$, respectively. 
On the contrary, the same reaction procedure applied at the compound $12 R$ to synthesize the ribopyranoside $17 R$ failed. In this case, the only product isolated in good yield (69\%) was the butenolide 21 (Scheme 4), deriving from an elimination-rearrangement of the pyranosidic ring.

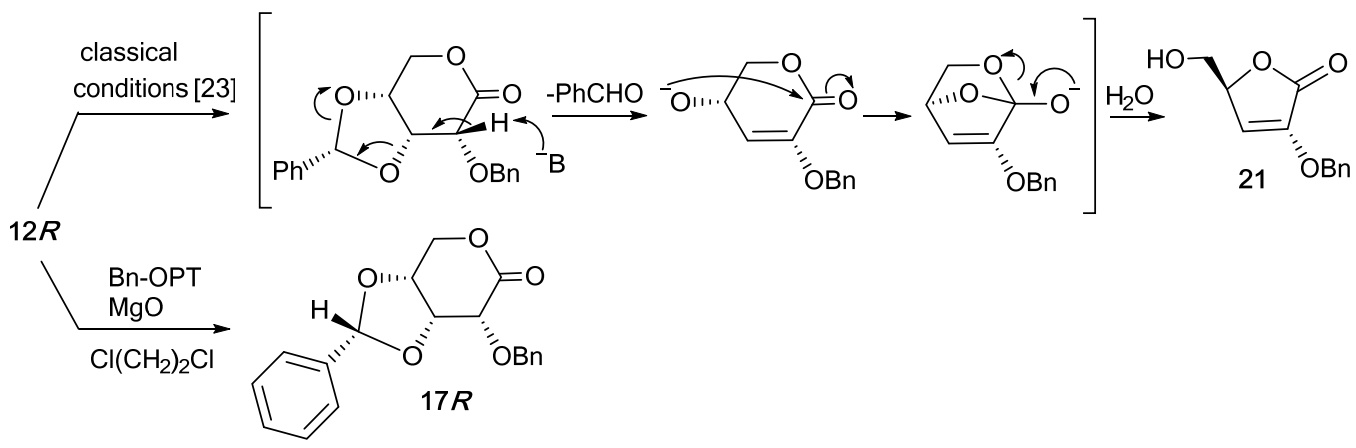

Scheme 4. Benzylation of $\mathbf{1 2 R}$ under classical conditions [20-23] and mild conditions.

This result was supported by Bigorra et al.'s observation on the behavior of 2-Oprotected ribopyranoses under basic conditions [34]. In the same work [34], the authors obtained the desired ribopyranoside $17 R$ in good yields $(60 \%)$, starting from compound $12 R$ and using benzyl bromide in the presence of $\mathrm{Ag}_{2} \mathrm{O}$ in THF. Unfortunately, by repeating the same procedure, we were not able to isolate compound $17 R$, but a mixture of unidentified substances was obtained. So, we thought to use the 2-benzyloxy-1-methylpyridinium triflate (Bn-OPT) as a benzylating agent operating under mild and nearly neutral conditions $[35,36]$. Under our optimal conditions, ribopyranoside $\mathbf{1 7} R$ was obtained in good yield $(61 \%)$, showing correct chemical-physical properties and ${ }^{1} \mathrm{H}$ and ${ }^{13} \mathrm{C}$ NMR spectra in DMSO (data not reported), superimposable to those described by Bigorra et al. [34]. The different protections make these compounds available as building blocks for the various requirements of the carbohydrate chemistry strategies; moreover, they allow useful structural study.

NMR analysis techniques applied to a thorough structural study of compounds with biological or pharmacological applications is a well-established practice in medicinal chemistry [37-40] and of fundamental importance to unequivocally identify synthesis products [41]. The structural assignments of all obtained compounds (Tables 1 and 2) were based on a detailed analysis of the $1 \mathrm{D}$ and $2 \mathrm{D}{ }^{1} \mathrm{H}$ - and ${ }^{13} \mathrm{C}-\mathrm{NMR}$ spectra also involving n.O.e. studies, giving significant information about all ${ }^{1} \mathrm{H}^{-1} \mathrm{H}$ interactions.

Table 1. ${ }^{1} \mathrm{H}$ NMR chemical shifts (ppm) of $R$ and $S$ epimers of 11, 18-20 and $R$ epimers of 12, 15-17.

\begin{tabular}{|c|c|c|c|c|c|c|c|c|c|c|c|c|}
\hline Proton & $\begin{array}{c}11 R \\
\mathrm{CDCl}_{3} \\
\end{array}$ & $\begin{array}{c}11 S \\
\mathrm{CDCl}_{3} \\
\end{array}$ & $\begin{array}{c}12 R \\
\text { DMSO }\end{array}$ & $\begin{array}{c}15 R \\
\mathrm{CDCl}_{3} \\
\end{array}$ & $\begin{array}{c}16 R \\
\mathrm{CDCl}_{3} \\
\end{array}$ & $\begin{array}{c}17 R \\
\mathrm{CDCl}_{3} \\
\end{array}$ & $\begin{array}{c}18 R \\
\mathrm{CDCl}_{3} \\
\end{array}$ & $\begin{array}{c}18 S \\
\mathrm{CDCl}_{3} \\
\end{array}$ & $\begin{array}{c}19 R \\
\mathrm{CDCl}_{3} \\
\end{array}$ & $\begin{array}{c}195 \\
\mathrm{CDCl}_{3} \\
\end{array}$ & $\begin{array}{c}20 R \\
\mathrm{CDCl}_{3} \\
\end{array}$ & $\begin{array}{c}20 \mathrm{~S} \\
\mathrm{CDCl}_{3} \\
\end{array}$ \\
\hline 2 & 4.99 & 5.09 & 4.64 & 5.55 & 4.50 & 4.11 & 4.94 & 5.04 & $4.87-4.90^{\mathrm{b}}$ & 5.0 & 4.95 & 5.08 \\
\hline 3 & 4.94 & 4.87 & 4.70 & 4.87 & 4.73 & 4.78 & 4.88 & 4.79 & $4.87-4.90^{\mathrm{b}}$ & 4.81 & 4.88 & 4.80 \\
\hline 4 & 4.79 & 4.82 & 4.62 & 4.73 & 4.60 & 4.56 & 4.92 & 4.95 & 4.76 & 4.80 & 4.81 & 4.84 \\
\hline $5 a$ & 3.89 & 3.89 & 4.33 & 4.40 & 4.23 & 4.15 & 4.31 & 4.30 & 3.88 & 3.88 & \multirow{2}{*}{$3.72-3.81^{\mathrm{a}}$} & \multirow{2}{*}{$3.73-3.78^{\circ}$} \\
\hline $5 b$ & 4.05 & 4.04 & 4.43 & 4.62 & 4.48 & 4.49 & 4.44 & 4.43 & 3.95 & 3.94 & & \\
\hline $\mathrm{O}_{2} \mathrm{CHPh}$ & 6.00 & 6.00 & 5.74 & 5.83 & 5.79 & 5.76 & 6.03 & 6.02 & 5.99 & 5.98 & 5.98 & 6.03 \\
\hline aromatics & $7.42-7.50^{b}$ & $7.41-7.49$ b & $7.39-7.44^{\mathrm{b}}$ & $7.39-7.49^{\mathrm{b}}$ & $7.39-7.48$ b & $7.29-7.50^{\mathrm{b}}$ & $7.42-7.49$ b & $7.42-7.48^{b}$ & $7.42-7.50^{b}$ & $7.40-7.43^{b}$ & $7.28-7.48^{\text {b }}$ & $7.36-7.48^{b}$ \\
\hline $\mathrm{OCH}_{2} \mathrm{Ph}$ & & & & & & $\begin{array}{l}4.74 \\
5.10\end{array}$ & & & & & $\begin{array}{l}4.52 \\
4.62\end{array}$ & $\begin{array}{l}4.51 \\
4.62\end{array}$ \\
\hline $\mathrm{OCOCH}_{3}$ & & & & 2.28 & & & 2.13 & 2.11 & & & & \\
\hline $\mathrm{CH}_{3} \mathrm{Si}$ & & & & & 0.17 & & & & 0.12 & 0.10 & & \\
\hline $\mathrm{CH}_{3} \mathrm{Si}$ & & & & & 0.25 & & & & 0.11 & 0.11 & & \\
\hline$\left(\mathrm{CH}_{3}\right)_{3} \mathrm{Si}$ & & & & & 0.98 & & & & 0.91 & 0.91 & & \\
\hline
\end{tabular}

${ }^{\mathrm{a}} \mathrm{AB}$ part of $\mathrm{ABX}$ system. ${ }^{\mathrm{b}}$ overlapped. 
Table 2. ${ }^{13} \mathrm{C}$ NMR chemical shifts (ppm) of $R$ and $S$ epimers of $\mathbf{1 1}, \mathbf{1 8}-\mathbf{2 0}$ and $R$ epimers of 12, 15-17.

\begin{tabular}{|c|c|c|c|c|c|c|c|c|c|c|c|c|}
\hline Carbon & $\begin{array}{c}11 R \\
\mathrm{CD}_{3} \mathrm{OD}\end{array}$ & $\begin{array}{c}11 S \\
\mathrm{CDCl}_{3}\end{array}$ & $\begin{array}{c}12 R \\
\text { DMSO }\end{array}$ & $\begin{array}{c}15 R \\
\mathrm{CDCl}_{3}\end{array}$ & $\begin{array}{c}16 R \\
\mathrm{CDCl}_{3}\end{array}$ & $\begin{array}{c}17 R \\
\mathrm{CDCl}_{3}\end{array}$ & $\begin{array}{c}18 R \\
\mathrm{CDCl}_{3}\end{array}$ & $\begin{array}{c}18 S \\
\mathrm{CDCl}_{3}\end{array}$ & $\begin{array}{c}19 R \\
\mathrm{CDCl}_{3}\end{array}$ & $\begin{array}{c}19 S \\
\mathrm{CDCl}_{3}\end{array}$ & $\begin{array}{c}20 R \\
\mathrm{CDCl}_{3}\end{array}$ & $\begin{array}{c}20 \mathrm{~S} \\
\mathrm{CDCl}_{3}\end{array}$ \\
\hline 1 & 176.1 & 173.9 & 171.9 & $165.5^{a}$ & 169.4 & 168.4 & $169.8^{\mathrm{a}}$ & $169.7^{a}$ & 172.9 & 173.0 & 173.3 & 174.6 \\
\hline 2 & 77.3 & 76.4 & 73.1 & 68.4 & 70.0 & 72.9 & 75.5 & 75.3 & 75.9 & 76.4 & 75.9 & 73.4 \\
\hline 3 & 81.7 & 77.7 & 76.1 & 74.5 & 77.8 & 75.9 & 79.5 & 78.8 & 81.6 & 77.8 & 80.2 & 78.8 \\
\hline 4 & 84.2 & 84.5 & 68.0 & 73.4 & 73.5 & 73.4 & 79.0 & 79.3 & 80.1 & 84.1 & 80.5 & 82.8 \\
\hline 5 & 62.4 & 62.3 & 67.0 & 67.5 & 67.3 & 67.2 & 63.6 & 63.5 & 63.0 & 63.2 & 69.1 & 68.9 \\
\hline $\mathrm{O}_{2} \mathrm{CHPh}$ & 107.7 & 104.9 & 104.0 & 105.0 & 104.7 & 104.8 & 107.3 & 107.2 & 106.6 & 104.6 & 106.9 & 104.7 \\
\hline aromatics & $\begin{array}{l}128.1 \\
129.4 \\
131.1 \\
137.5\end{array}$ & $\begin{array}{l}126.6 \\
128.7 \\
130.0 \\
135.8\end{array}$ & $\begin{array}{l}126.9 \\
128.1 \\
129.9 \\
134.7\end{array}$ & $\begin{array}{l}127.3 \\
128.6 \\
130.4 \\
134.5\end{array}$ & $\begin{array}{l}126.6 \\
128.5 \\
130.2 \\
135.4\end{array}$ & $\begin{array}{l}136.7 \\
134.8 \\
130.2 \\
128.7 \\
128.5 \\
128.3 \\
128.3 \\
127.4\end{array}$ & $\begin{array}{l}126.9 \\
128.7 \\
130.4 \\
135.0\end{array}$ & $\begin{array}{l}126.8 \\
128.6 \\
130.2 \\
134.9\end{array}$ & $\begin{array}{l}126.8 \\
128.5 \\
130.0 \\
135.3\end{array}$ & $\begin{array}{l}126.6 \\
128.5 \\
129.8 \\
135.7\end{array}$ & $\begin{array}{l}127.0 \\
127.9 \\
128.3 \\
128.7 \\
128.8 \\
130.2 \\
135.4 \\
137.0\end{array}$ & $\begin{array}{l}127.3 \\
127.9 \\
128.1 \\
128.4 \\
128.8 \\
130.1 \\
135.0 \\
136.8\end{array}$ \\
\hline $\mathrm{OCOCH}_{3}$ & & & & 20.5 & & & 20.8 & 20.6 & & & & \\
\hline $\mathrm{OCOCH}_{3}$ & & & & $169.9^{a}$ & & & $172.3^{a}$ & $172.2^{\mathrm{a}}$ & & & & \\
\hline $\mathrm{OCH}_{2} \mathrm{Ph}$ & & & & & & 72.8 & & & & & 74.1 & 72.6 \\
\hline $\mathrm{CH}_{3} \mathrm{Si}$ & & & & & $\begin{array}{l}-4.2 \\
-5.2 \\
\end{array}$ & & & & $\begin{array}{l}-5.6 \\
-5.8\end{array}$ & $\begin{array}{l}-5.6 \\
-5.8\end{array}$ & & \\
\hline$\left(\mathrm{CH}_{3}\right)_{3} \mathrm{CSi}$ & & & & & 25.9 & & & & 24.9 & 25.8 & & \\
\hline C-Si & & & & & 18.6 & & & & 18.2 & 18.2 & & \\
\hline
\end{tabular}

${ }^{1} \mathrm{H}-\mathrm{NMR}$ studies dealing with vicinal coupling constants have revealed some useful models (Table 3) which also allow for differentiation between different sugar-related lactones. Smaller coupling occurrences between $\mathrm{H}-2$ and $\mathrm{H}-3$ were found for pyranoside lactones $\mathbf{1 2} \boldsymbol{R}-\mathbf{1 7} \boldsymbol{R}\left(J_{2,3}=3.2-3.3 \mathrm{~Hz}\right)$ in comparison with those for furanoside lactones $\mathbf{1 1} \boldsymbol{R}$, $18 R-20 R$ and 11S, 18S-20S $\left(J_{2,3}=5.6-6.0 \mathrm{~Hz}\right)$. In addition, high values had been found for $\mathrm{H}-3, \mathrm{H}-4$ coupling in $\mathbf{1 2 R}-\mathbf{1 7 R}\left(J_{3,4}=8.1-8.4 \mathrm{~Hz}\right)$, while they are nearly absent in the $R$ and $S$ epimers of 11, 18-20 $\left(J_{3,4}<1 \mathrm{~Hz}\right)$. The n.O.e. experiments performed with selected lactones disclosed other important information about the structural characteristic, and also confirmed the results deduced from coupling constant analysis. The correlations between H-3 and H-4 in compound $\mathbf{1 2 R}$ and their absence in the $R$ and $S$ epimers of compound $\mathbf{1 1}$ suggested that, in the first compound, $\mathrm{H}-3$ and $\mathrm{H}-4$ are syn, as in the pyranoside ring, while in the second ones, the $\mathrm{H}-3$ and $\mathrm{H}-4$ are anti, as in the furanoside ring.

${ }^{13} \mathrm{C}-\mathrm{NMR}$ spectroscopy has been previously proposed as a useful tool to establish the size of the lactone ring, supported by considerable differences in the chemical shifts found for C-3 and C-4 in the lactones studied [43]. Thus, the chemical shifts of C-3 and $\mathrm{C}-4$ in the six-membered lactones $(\mathbf{1 2 R}, \mathbf{1 5 R} \mathbf{- 1 7 R})$ are all within the range of $68.0-77.8 \mathrm{ppm}$ (Table 2), whereas in the five-membered lactones $(\mathbf{1 1}, \mathbf{1 8}-\mathbf{2 0})$, the $C-3$ resonates in the range of 77.7-81.7 ppm and C-4 resonates at lower field in the range of 79.0-84.5 ppm. Also, the signal for C-5 in the lactones $12 R, \mathbf{1 5 R}-\mathbf{1 7} R$ is at a lower field (67.0-67.5 ppm) than that for C-5 in both $R$ and $S$ epimers of furanose lactones 11, 18 and 19 (62.3-63.6 ppm). Only compounds $20 R$ and $20 S$ make an exception to this trend in chemical shifts due to the benzoylation at the position 5 . 
Table 3. ${ }^{1} \mathrm{H}$ NMR coupling constants $(\mathrm{Hz})^{\mathrm{a}}$ of $R$ and $S$ epimers of 11, 18-20 and $R$ epimers of 12, 15-17.

\begin{tabular}{|c|c|c|c|c|c|c|c|c|c|c|c|c|}
\hline $\begin{array}{l}\text { Coupled } \\
\text { Protons }\end{array}$ & $\begin{array}{c}11 R \\
\mathrm{CDCl}_{3}\end{array}$ & $\begin{array}{c}11 S \\
\mathrm{CDCl}_{3}\end{array}$ & $\begin{array}{c}12 R \\
\text { DMSO }\end{array}$ & $\begin{array}{c}15 R \\
\mathrm{CDCl}_{3}\end{array}$ & $\begin{array}{c}16 R \\
\mathrm{CDCl}_{3}\end{array}$ & $\begin{array}{c}17 R \\
\mathrm{CDCl}_{3}\end{array}$ & $\begin{array}{c}18 R \\
\mathrm{CDCl}_{3}\end{array}$ & $\begin{array}{c}18 S \\
\mathrm{CDCl}_{3}\end{array}$ & $\begin{array}{c}19 R \\
\mathrm{CDCl}_{3}\end{array}$ & $\begin{array}{c}19 S \\
\mathrm{CDCl}_{3}\end{array}$ & $\begin{array}{c}20 R \\
\mathrm{CDCl}_{3}\end{array}$ & $\begin{array}{c}20 S \\
\mathrm{CDCl}_{3}\end{array}$ \\
\hline & $\underset{\text { (calc) }}{\exp }$ & $\underset{\text { (calc) }}{\exp }$ & $\underset{(\text { calc) }}{\exp }$ & $\exp$ & $\exp$ & $\exp$ & $\exp$ & $\exp$ & $\exp$ & $\exp$ & $\exp$ & $\exp$ \\
\hline 2,3 & $\begin{array}{c}6.0^{a} \\
(6.96)^{b}\end{array}$ & $5.7(7.47)$ & $3.3(2.09)$ & 3.2 & 3.2 & 3.2 & 5.9 & 5.8 & n.d. & 5.6 & 5.7 & 5.6 \\
\hline 3,4 & $<1(1.04)$ & $<1(1.10)$ & $8.2(7.54)$ & 8.1 & 8.4 & 8.1 & $<1$ & $<1$ & $<1$ & $<1$ & $<1$ & $<1$ \\
\hline $4,5 a$ & $2.1(3.63)$ & $2.3(4.95)$ & $<1(2.75)$ & $<1$ & $<1$ & 1.7 & 2.4 & 2.7 & 1.4 & 1.9 & 1.9 & 1.4 \\
\hline $4,5 b$ & $1.3(1.01)$ & $1.8(3.85)$ & $<1(1.49)$ & $<1$ & $<1$ & $<1$ & 2.3 & 2.7 & 2.0 & 2.1 & 2.1 & 1.9 \\
\hline $5 a, 5 b$ & 12.2 & 12.2 & 13.2 & 13.4 & 12.8 & 13.3 & 12.4 & 12.4 & 11.5 & 11.2 & n.d. & n.d. \\
\hline $\mathrm{OCH}_{2} \mathrm{Ph}$ & & & & & & 12.4 & & & & & 11.8 & 11.8 \\
\hline
\end{tabular}

${ }^{\mathrm{a}}$ experimental error in the measured ${ }^{1} \mathrm{H}-{ }^{1} \mathrm{H}$ coupling constants was $\pm 0.5 \mathrm{~Hz} .{ }^{\mathrm{b}}$ weight average of the values calculated with the HaasnootAltona equation [42] from the corresponding dihedral angle for each conformer and the mole fraction with which it is present in the Boltzmann population at $298 \mathrm{~K}$.

In addition, in previous reports [33,44], describing both acetalic epimers of the 2phenyl-1,3-dioxolanes, the relative $R$ and $S$ configuration was identified by (i) the acetal proton signal which is normally found at a higher field in the $R$ than in the corresponding $S$ isomer and (ii) the ${ }^{13} \mathrm{C}$ shift of the acetal carbon atom is found at a higher field in the $S$ than in the corresponding $R$ isomer, in $\mathrm{CDCl}_{3}$ solutions. In our case, for the compounds 11, 18-20, while ${ }^{13} \mathrm{C}$ NMR results (Table 2) are consistent with the previous observations, the acetal proton signals in the ${ }^{1} \mathrm{H}-\mathrm{NMR}$ spectra are not significant to discriminate between the two epimers (Table 1).

Finally, the correct identification of the two epimers $11 R$ and $11 S$ can be unequivocally obtained by n.O.e. experiments, where only in the $R$ isomer the acetal proton correlates with the $\mathrm{H}-2$ and $\mathrm{H}-3$ protons, due to their presence at the same side of the carbohydrate ring.

\subsection{Computational Studies}

To rationalize the described results and to obtain further useful information on the acetalization reaction described in the work, a molecular modeling study was carried out on the $R$ and $S$ acetal epimers of the compounds 10, 11, 12 and 13 (Scheme 2). Compound $\mathbf{1 4}$ was excluded due to the high steric strain in its structure, which makes its existence unlikely.

The conformational space of each compound was explored with a molecular mechanics model, the MMFF force field implemented in Spartan 14 (see experimental) obtaining a selection of low-energy conformers. The structures of the conformers obtained were subjected (in vacuum) to a higher-level geometry optimization and a single-point energy calculation by a hybrid DFT approach at the B3LYP/6-31G* level.

Then, based on the relative energy differences of each conformer compared to that of the corresponding global minimum, the population at $298 \mathrm{~K}$ of conformers for each compound, according to the Boltzmann equation, has been estimated.

Finally, the energies of the different compounds were calculated as a weight average based on the energy and the corresponding mole fraction of their conformers.

In the benzylidenation reaction carried out in the presence of an aqueous acid, all the equilibrium represented in Scheme 2 are operative.

On the basis of the energies calculated for the various potential products, the mixture obtained from this reaction, under thermodynamic control, should consist almost exclusively of the compound $12 R(62.5 \%)$, which has the lowest energy, accompanied by its epimer $12 \mathrm{~S}\left(36.3 \%, \Delta \mathrm{E}_{\text {rel }}=1.34 \mathrm{~kJ} / \mathrm{mol}\right)$, while the other compounds $11 R$ $\left(\Delta \mathrm{E}_{\text {rel }}=11.75 \mathrm{~kJ} / \mathrm{mol}\right), 11 S\left(\Delta \mathrm{E}_{\text {rel }}=12.39 \mathrm{~kJ} / \mathrm{mol}\right), 13 S\left(\Delta \mathrm{E}_{\text {rel }}=15.34 \mathrm{~kJ} / \mathrm{mol}\right), \mathbf{1 3 R}$ $\left(\Delta \mathrm{E}_{\mathrm{rel}}=16.41 \mathrm{~kJ} / \mathrm{mol}\right), 10 R\left(\Delta \mathrm{E}_{\mathrm{rel}}=41.36 \mathrm{~kJ} / \mathrm{mol}\right)$, and $10 S\left(\Delta \mathrm{E}_{\mathrm{rel}}=45.24 \mathrm{~kJ} / \mathrm{mol}\right)$, should be present only in trace amounts. 
In the reaction in the presence of concentrated $\mathrm{HCl}$ described in this work, only the compound $12 R$ in $81 \%$ yield was obtained by separation after addition of $\mathrm{Et}_{2} \mathrm{O}$ to the reaction mixture. The obtaining of only the compound $12 R$ with a higher yield than that expected by molecular modeling calculations could be explained both by considering that its insolubility, and therefore its separation from the mixture during the proceeding of the reaction, can shift the equilibrium towards its formation, and the possibility that its $\mathbf{1 2 S}$ epimer, if present, could remain in the reaction mixture after the direct separation of $\mathbf{1 2} R$ by $\mathrm{Et}_{2} \mathrm{O}$ addition.

The reaction between ribonolactone $\mathbf{2}$ (and other pentonolactones) and benzaldehyde was investigated in detail in 1994 by Han et al. [29] by molecular mechanics (MM2) and semiempirical (PM3 and AM1) calculations on the conformation and thermodynamic stability of the main products, to obtain information on the equilibrium composition of the reaction.

The data obtained from these calculations, however, show that none of the computational methods utilized produced completely correct results. In fact, the molecular mechanics calculations often accurately reproduce the structural geometry of molecules but do not give reliable energy data, for different structural isomers, while semiempirical methods predict more reliable energy values, but are less accurate in predicting the geometric structure of compounds. On the other hand, in the years in which the work was done, higher-level calculations, such as ab initio approaches that give structural geometry and energy results more accuracy, still had excessive computational costs for the relatively large molecules studied.

When the benzylidenation reaction is carried out under non-aqueous conditions, the ring expansion from furanosic 1,4-lactone to give pyranosic 1,5-lactone, via intermediate aldonic acid 9 derivatives, cannot take place. In this case, only the $R$ and $S$ acetal epimers of compounds 10 and $\mathbf{1 1}$ can be formed. Based on the energies calculated for these compounds, the thermodynamic equilibrium mixture of the reaction under anhydrous conditions should consist of $\mathbf{1 1 R}(56.5 \%)$, which has the lowest energy and its $\mathbf{1 1 S}$ epimer (43.5\%, $\left.\Delta \mathrm{E}_{\mathrm{rel}}=0.64 \mathrm{~kJ} / \mathrm{mol}\right)$, with only traces of compounds $10 R\left(\Delta \mathrm{E}_{\mathrm{rel}}=29.61 \mathrm{~kJ} / \mathrm{mol}\right)$ and $10 S$ $\left(\Delta \mathrm{E}_{\mathrm{rel}}=33.49 \mathrm{~kJ} / \mathrm{mol}\right)$.

To obtain useful information in support of the results of the NMR studies on the $R$ and $S$ epimers of compounds 11 and 12, the energy of their conformers, and consequently, the distribution of the corresponding populations, was recalculated considering the solvents used in the NMR experiments. For each conformer, the energy was re-optimized at the B3LYP/6-31G* theory level with the SM8 solvation model, included in Spartan 14, to consider the solvation energy because of the solvent environment $\left(\mathrm{CHCl}_{3}\right.$ for $\mathbf{1 1}$ and DMSO for 12). Then, based on the calculated energies, the Boltzmann distribution of the conformer populations of the $R$ and $S$ epimers of 11 in $\mathrm{CHCl}_{3}$ and 12 in DMSO was determined (Tables S1-S4 in Supplementary Materials).

The results of the calculations indicate that the compounds $12 R$ and $12 S$ in DMSO at $298 \mathrm{~K}$ are present for more than $99.9 \%$ in a single conformation (Figure 2, Tables S1 and S2 in Supplementary Materials). In both compounds, there is an intramolecular hydrogen bond between the hydroxyl in position 2 and the oxygen of the adjacent carbonyl with the followed geometry: for $12 R \mathrm{O} \cdots \mathrm{H}$ distance $=2.084 \AA$, H-O distance $=0.976 \AA$; $\cdots \mathrm{O}-\mathrm{H}$ angle $=117.90^{\circ}$, for $12 S$ the corresponding values are: $2.070 \AA, 0.977 \AA$ and $118.60^{\circ}$.

Furthermore, for both compounds, the 1,5 lactone ring assumes a boat conformation $(2,5 \mathrm{~B})$, as described by the puckering parameters $[45,46]$, identical for the two compounds (puckering amplitude $Q=0.70 \AA$, pseudorotation phase angles $\Phi=86^{\circ}$ and $\phi=127^{\circ}$ ).

In the case of 11, its $R$ and $S$ epimers in $\mathrm{CHCl}_{3}$ at $298 \mathrm{~K}$ are present as mixtures of conformers. Compound $11 R$ consists of more than $95 \%$ of two conformers in a ratio of 89:11 (Figure 3, Table S3 in Supplementary Materials). The two conformers have the lactone ring atoms perfectly superimposable in space and the furanoside lactone ring assumes an envelope $\left(E_{3}\right)$ conformation as described by the puckering parameters (puckering amplitude $q_{2}=0.22 \AA$ and pseudorotation phase angle $\phi_{2}=108^{\circ}$ ). 


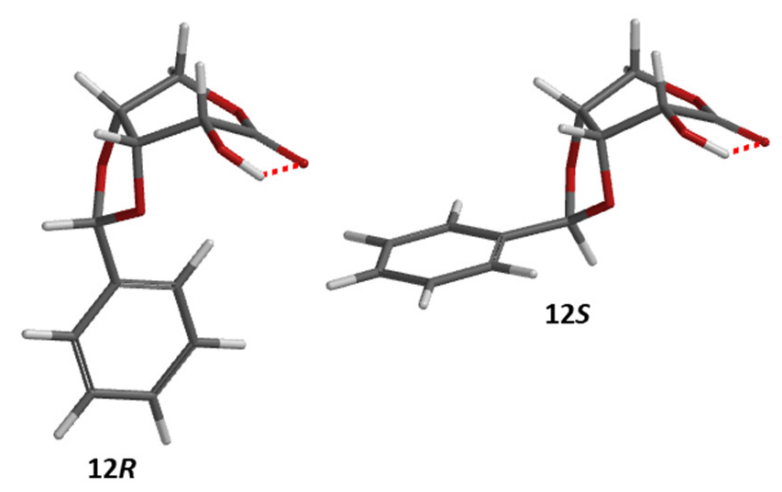

Figure 2. Lower energy conformer calculated in DMSO at $298 \mathrm{~K}$, of $\mathbf{1 2 R}$ ( $>99 \%$ of population) and $12 S$ ( $>99 \%$ of population).
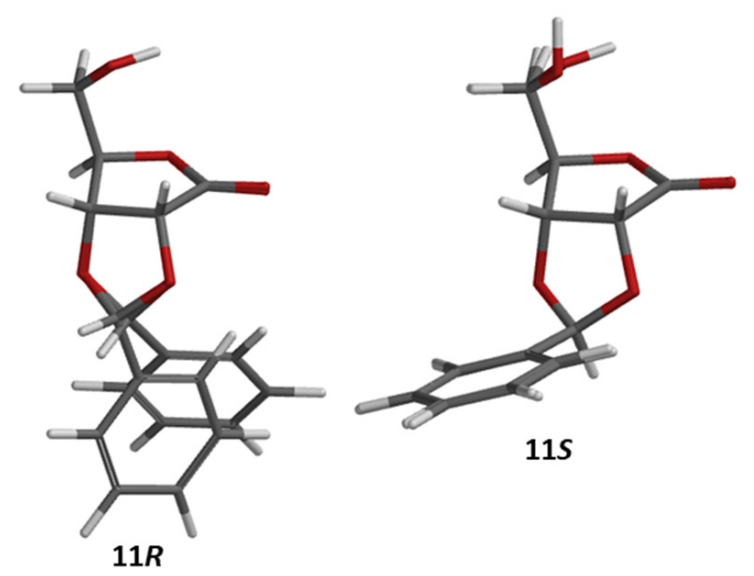

Figure 3. Superposition of the lactone ring of the two lower-energy conformers, calculated in $\mathrm{CHCl}_{3}$ at $298 \mathrm{~K}$ of $\mathbf{1 1 R}$ (95\% of the population) and $\mathbf{1 1 S}$ ( $88 \%$ of the population).

Finally, the compound $11 \mathrm{~S}$ in $\mathrm{CHCl}_{3}$ at $298 \mathrm{~K}$ is present as a mixture of conformers, constituted for over $88 \%$ by two conformers in the ratio 71:29 (Figure 3, Table S4 in Supplementary Materials). These two conformers mainly differ in the different orientation of the 4-hydroxymethyl group, but also for these conformers the lactone ring atoms are perfectly superimposable in space.

The puckering parameters of the furanosidic lactone rings, identical for these two main conformers (puckering amplitude $q_{2}=0.20 \AA$ and pseudorotation phase angle $\phi_{2}=122^{\circ}$ ), indicate a conformation of the ring intermediate between twist and envelope $\left({ }^{4} T_{3} / E_{3}\right)$.

The values of the coupling constants of the vicinal protons for the compounds 11R, $11 S$ and $12 R$ were then calculated.

For each conformer present in the populations of these compounds, the vicinal ${ }^{1} \mathrm{H}$ coupling constants were calculated from the corresponding $\mathrm{H}-\mathrm{C}-\mathrm{C}-\mathrm{H}$ dihedral angles using a Karplus-type equation with the Haasnoot-Altona parameterization [42], accounting for the coupling dependence not only on the dihedral angle, but also on the electronegativity of the participating atoms, and on the orientation of the $\alpha$ - and $\beta$-substituents. Then, the values of the ${ }^{3} \mathrm{~J}(\mathrm{H}, \mathrm{H})$ coupling constants in the compounds $11 R, \mathbf{1 1 S}$ and $\mathbf{1 2} R$ were obtained weighting average based on the population percentages.

The calculated values (Table 3 ) for these constants agree with those experimentally observed, thus strongly supporting the assignments made.

In a similar way, the distances between the hydrogen atoms in the compounds (Table 4) were calculated as the weight average of the corresponding distance in the individual conformers and their abundance in the population. 
Table 4. Experimentally observed n.O.e. and H-H calculated distances for compounds 11R, 11S, and $12 R$.

\begin{tabular}{|c|c|c|c|c|c|c|}
\hline \multirow[b]{2}{*}{$\begin{array}{c}\text { Proton } \\
\text { Pair }\end{array}$} & \multicolumn{2}{|c|}{$11 R$} & \multicolumn{2}{|c|}{$11 S$} & \multicolumn{2}{|c|}{$12 R$} \\
\hline & n.O.e. & H-H (̊̊) ${ }^{a}$ & n.O.e. & H-H (̊̊) ${ }^{a}$ & n.O.e. & H-H (Å) ${ }^{a}$ \\
\hline $\mathrm{H}^{\text {acetal }}-\mathrm{H}^{2}$ & + & 3.46 & - & 3.98 & + & 4.82 \\
\hline $\mathrm{H}^{\text {acetal }}-\mathrm{H}^{3}$ & + & 2.90 & - & 3.81 & + & 2.78 \\
\hline $\mathbf{H}^{\text {acetal }}-\mathrm{H}^{4}$ & - & 4.49 & - & 4.28 & - & 3.14 \\
\hline $\mathrm{H}^{\text {acetal }}-\mathrm{H}^{2 \prime}$ & - & 3.68 & - & 3.27 & - & 3.78 \\
\hline $\mathbf{H}^{\text {acetal }}-\mathrm{H}^{6 \prime}$ & + & 2.47 & + & 3.04 & + & 2.35 \\
\hline $\mathbf{H}^{3}-\mathbf{H}^{4}$ & - & 2.80 & - & 2.81 & + & 2.39 \\
\hline
\end{tabular}

a weight average of the calculated distances in the conformers as a function of their abundance in the population of the compound.

\section{Material and Methods}

\subsection{Chemistry}

Chemicals and solvents were obtained from Sigma-Aldrich (Merck, Darmstadt, Germany) and used without further purification. Column chromatography was performed on silica gel 60 (70-230 mesh) using the specified eluents. The progress of the reactions was monitored by analytical thin-layer chromatography (TLC) on pre-coated glass plates (silica gel 60 F254-plate-Merck, Darmstadt, Germany) and the products were visualized by UV light, anisaldehyde $/ \mathrm{H}_{2} \mathrm{SO}_{4} / \mathrm{EtOH}$ solution with heat as the developing agent. Optical rotations were taken on a PerkinElmer 241 polarimeter equipped with a $1 \mathrm{dm}$ tube; $[\alpha]_{D}$ values are given in $10^{-1} \mathrm{deg} \mathrm{cm} \mathrm{g}^{-1}$. Purity of all compounds ( $\left.>99 \%\right)$ was verified by thin-layer chromatography and NMR measurements [47-50].

\subsection{NMR Analysis}

NMR spectra were recorded on a Bruker AVANCE 500 spectrometer equipped with a $5 \mathrm{~mm}$ broadband reverse probe and deuterium lock with field z-gradient operating at 500.13 and $125.76 \mathrm{MHz}$ for ${ }^{1} \mathrm{H}$ and ${ }^{13} \mathrm{C}$, respectively. All NMR spectra were recorded at $298 \mathrm{~K}$ in $\mathrm{CDCl}_{3}$ or in DMSO- $d_{6}$ (isotopic enrichment $99.98 \%$ ) solution and the chemical shifts were reported on a $\delta(\mathrm{ppm})$ scale. The central peak of DMSO- $d_{6}$ signals $(2.49 \mathrm{ppm}$ for ${ }^{1} \mathrm{H}$ and $39.50 \mathrm{ppm}$ for ${ }^{13} \mathrm{C}$ ) and of $\mathrm{CDCl}_{3}$ signals $\left(7.26 \mathrm{ppm}\right.$ for ${ }^{1} \mathrm{H}$ and $77.0 \mathrm{ppm}$ for $\left.{ }^{13} \mathrm{C}\right)$ were used as internal reference standard. Acquisition parameters for 1D were as follows: ${ }^{1} \mathrm{H}$ spectral width of $5000 \mathrm{~Hz}$ and $32 \mathrm{~K}$ data points providing a digital resolution of ca. $0.305 \mathrm{~Hz}$ per point, relaxation delay $2 \mathrm{~s} ;{ }^{13} \mathrm{C}$ spectral width of $29,412 \mathrm{~Hz}$ and $64 \mathrm{~K}$ data points providing a digital resolution of ca. $0.898 \mathrm{~Hz}$ per point, relaxation delay $2.5 \mathrm{~s}$. The experimental error in the measured ${ }^{1} \mathrm{H}-{ }^{1} \mathrm{H}$ coupling constants was $\pm 0.5 \mathrm{~Hz}$.

\subsection{Computational Procedures}

Computational study of compounds $10 R-13 R$ and $10 S-13 S$ was performed with the software Spartan '14 (Wavefunction, Inc., Irvine, CA, USA) using the default parameters unless otherwise indicated.

Each compound was subjected to a systematic search of the conformational space using MMFF force field in vacuum, to identify the low-energy conformers, and the structures within $50 \mathrm{~kJ} / \mathrm{mol}$ of the global minimum were saved. The used "conformer distribution" function in Spartan automatically utilized the systematic search method due to the low number of conformational degrees of freedom in the studied molecules.

The geometry of the obtained conformers was fully re-optimized ("Equilibrium Geometry" function) at a higher-level geometry optimization using a density functional method (B3LYP) with the 6-31G* basis set. A single-point energy calculation was then performed 
("Energy" function with into options for the keywords: GRADIENTTOLERANCE = 1E-9, OPTCYCLE $=30,000$ and GEOMETRYCYCLE $=30,000$ ).

To confirm that the structures are in local minima, the normal-mode frequencies of the optimized conformational isomers were calculated. Each vibration spectrum does not show any negative frequency values, confirming that the optimized structure is at the lowest point.

The conformer populations for each compound were calculated based on the relative energy of a given conformer with respect to the global minimum, using the well-known Boltzmann distribution equation.

The energies for the compounds $\mathbf{1 0 R}-\mathbf{1 3 R}$ and $\mathbf{1 0 S}-\mathbf{1 3 S}$ were calculated as the weight average considering for each compound, the energy of the single conformers and the mole fraction with which they are present in the conformer population.

For the NMR considerations, the energies of each conformer of $11 R, 11 S, 12 R$ and $12 S$ were re-optimized at the B3LYP/6-31G* level using the SM8 solvation model [51] included in the Spartan program package.

In the B3LYP /6-31G* single-point energy calculation, in addition to those indicated above, the keywords POSTSOLVENT = TRICHLOROMETHANE for 11R and $\mathbf{1 1 S}$ and POSTSOLVENT $=$ DIMETHYLSULFOXIDE for $\mathbf{1 2 R}$ and $\mathbf{1 2 S}$ were used. The energies thus obtained were utilized to determine the Boltzmann distribution of the conformers in $\mathrm{CHCl}_{3}$ for the compounds $11 R$ and $11 S$ in DMSO for the compounds $12 R$ and $12 S$.

The conformations of the furanose lactone rings in the main conformer of $11 R$ and of $11 S$ and those of the pyranose lactone rings in the main conformer of $12 R$ and $12 S$ were determined using Cremer-Pople puckering parameters [44], which define the conformation of a puckered ring in a quantitative and mathematically well-defined way [45].

For each conformer of the population of compounds $11 R, 11 S$ and $12 R$, the vicinal proton-proton coupling constants, ${ }^{3} \mathrm{~J}(\mathrm{H}, \mathrm{H})$, were calculated from the corresponding $\mathrm{H}-\mathrm{C}$ $\mathrm{C}-\mathrm{H}$ torsion angles using the Altona equation [42] based on the Pauling electronegativity of $\alpha$ and $\beta$ position atoms.

The ${ }^{3} \mathrm{~J}$ coupling constants and the distance between hydrogen atoms for compounds $11 R, 11 S$ and $12 R$ were calculated as the weight average considering the corresponding value in each conformer and the mole fraction with which the conformer is present in the population.

\subsection{3,4-O-(R)-Benzylidene-D-Ribono-1,5 Lactone (12R)}

To a solution of D-(+)-ribono-1,4-lactone $2(1.00 \mathrm{~g}, 6.75 \mathrm{mmol})$ in benzaldehyde $(9 \mathrm{~mL})$, concentrated hydrochloric acid $(0.9 \mathrm{~mL})$ was added and the mixture was stirred at room temperature. After 20 minutes, the formation of a precipitate begins, and it increases during the time. The reaction was stirred at room temperature overnight, and then, $\mathrm{Et}_{2} \mathrm{O}(20 \mathrm{~mL})$ was added to the semi-solid heterogeneous reaction mixture. A white solid was collected by filtration, and it was washed with $10 \%$ aqueous sodium bicarbonate $(10 \mathrm{~mL})$ and water $(10 \mathrm{~mL})$. Finally, the product was refluxed for 20 minutes in acetone $(100 \mathrm{~mL})$, then the mixture was left to cool at room temperature and the solid was filtered, yielding $12 R$ as a pure white solid ( $1.29 \mathrm{~g}, 81 \%$ yield), TLC (hexane/AcOEt; $3: 7$ v:v) $\mathrm{R}_{\mathrm{f}} 0.25 ; \mathrm{mp} 232-234{ }^{\circ} \mathrm{C}$ [lit. [30] 230-231.5 $\left.{ }^{\circ} \mathrm{C}\right] ;[\alpha]^{25} \mathrm{D}-173$ (c 1.0, DMF) [lit. [30] - 180.5 (c 0.47, DMF)].

\subsection{2,3-O-(R)-Benzylidene-D-Ribono-1,4-Lactone (11R) and}

2,3-O-(S)-Benzylidene-D-Ribono-1,4-Lactone (11S)

Method A: D-(+)-ribono-1,4-lactone $2(1.00 \mathrm{~g}, 6.75 \mathrm{mmol})$ was suspended with vigorous stirring in dry 1,2-dimethoxyethane (3 $\mathrm{mL})$-containing benzaldehyde $(5 \mathrm{~mL}, 49.23 \mathrm{mmol})$, then $\mathrm{ZnCl}_{2}(0.90 \mathrm{~g}, 6.60 \mathrm{mmol})$ was added, and the mixture was stirred at room temperature under an argon atmosphere. After $5 \mathrm{~h}$, water $(5 \mathrm{~mL})$ was added and the mixture was extracted with AcOEt $(3 \times 5 \mathrm{~mL})$, the organic layer was washed with water and aqueous $\mathrm{NaHCO}_{3}$, dried over anhydrous $\mathrm{Na}_{2} \mathrm{SO}_{4}$ and evaporated in vacuum. The residue was purified by flash chromatography on silica gel (hexane/AcOEt 6:4 v:v) to afford the compounds $11 R$ ( $877 \mathrm{mg}$, 55\% yield) and $\mathbf{1 1 S}$ (191 $\mathrm{mg}, 12 \%$ yield) as white solids. Compound 
11R showed: TLC (hexane/AcOEt 7:3 v:v) $\mathrm{R}_{\mathrm{f}}$ 0.13; mp 164-165 ${ }^{\circ} \mathrm{C}$, [lit. [30] 156-158 ${ }^{\circ} \mathrm{C}$, [34] $163-164{ }^{\circ} \mathrm{C}$ ]; $[\alpha]^{22} \mathrm{D}-78.0$ (c 0.5, $\mathrm{CHC1}_{3}$ ) [lit. [30] -79.1 (c 0.56, $\mathrm{CHC1}_{3}$ ) -70 (DMF)]. Compound $11 S$ showed: TLC (hexane/AcOEt 7:3 v:v) $\mathrm{R}_{\mathrm{f}} 0.21$; mp 86-87 ${ }^{\circ} \mathrm{C}$ [lit. [31] 83-84 ${ }^{\circ} \mathrm{C}$, [34] 87-88 ${ }^{\circ} \mathrm{C}$ ]; $[\alpha]^{22} \mathrm{D}-38\left(\right.$ c 1.0, $\left.\mathrm{CHC1}_{3}\right)$ [lit. [31] -39.3 (c 1.16, $\left.\mathrm{CHC}_{3}\right),[34$ ] $\left.-40\left(\mathrm{CHC1}_{3}\right)\right]$.

Method B: To a suspension of lactone $2(1.00 \mathrm{~g}, 6.75 \mathrm{mmol})$ in dry 1,2-dimethoxyethane $(4 \mathrm{~mL})$ were added benzaldehyde dimethyl acetal $(1.32 \mathrm{~mL}, 8.79 \mathrm{mmol})$ and a catalytic amount of anhydrous $\mathrm{SnCl}_{2}(11 \mathrm{mg}, 0.06 \mathrm{mmol})$. The reaction mixture was heated to reflux and stirred for $5 \mathrm{~h}$ under an argon atmosphere. After evaporation of the solvent under vacuum, the residue was purified by silica gel flash-column chromatography (hexane/AcOEt 6:4 v:v) to afford compounds $11 R$ (925 mg, 58\% yield) and $11 S$ (112 mg, 7\% yield) as white solids.

\subsection{General Procedure for the Acetylation}

To a solution of 11 or $12(0.40 \mathrm{mmol})$ in pyridine $(1 \mathrm{~mL})$, acetic anhydride $(0.06 \mathrm{~mL}$, $0.63 \mathrm{mmol}$ ) was added, and the reaction was stirred at room temperature for $3 \mathrm{~h}$. Then, the reaction mixture was diluted with $\mathrm{CH}_{2} \mathrm{Cl}_{2}(5 \mathrm{~mL})$, washed with $2 \mathrm{M} \mathrm{HCl}(3 \times 5 \mathrm{~mL})$, saturated solution of $\mathrm{NaHCO}_{3}(5 \mathrm{~mL})$, water $(5 \mathrm{~mL})$ and dried over anhydrous $\mathrm{Na}_{2} \mathrm{SO}_{4}$. The solvent was evaporated under reduced pressure and the crude residue was purified by flash chromatography on silica gel.

Starting from $\mathbf{1 1} R$, the acetyl derivative $\mathbf{1 8 R}$ was obtained (101 $\mathrm{mg}, 91 \%$ yield) showing: TLC (hexane/AcOEt 7:3 v:v); $\mathrm{R}_{\mathrm{f}} 0.31 ; \mathrm{mp} 144-145^{\circ} \mathrm{C}$ [lit. [31] $\left.143-144{ }^{\circ} \mathrm{C}\right] ;[\alpha]^{22} \mathrm{D}-51$ (c 1 , $\mathrm{CHC1}_{3}$ ) [lit. [31] -72.5 (c $\left.1.48, \mathrm{CHC1}_{3}\right)$ ].

Starting from $11 S$, the acetyl derivative $18 S$ was obtained (99 $\mathrm{mg}, 89 \%$ yield) showing: TLC (hexane/AcOEt 7:3 v:v); $\mathrm{R}_{\mathrm{f}} 0.46 ; \mathrm{mp} 85-86^{\circ} \mathrm{C}(\mathrm{dec}) ;[\alpha]^{22} \mathrm{D}-4$ (c $\left.1, \mathrm{CHC}_{3}\right)$.

Starting from $12 R$, the acetyl derivative $15 R$ was obtained (103 $\mathrm{mg}, 93 \%$ yield) showing: TLC (hexane/AcOEt 1:1 v:v); $\mathrm{R}_{\mathrm{f}}$ 0.26; mp 174-176 ${ }^{\circ} \mathrm{C}$ [lit [34] 173-174 $\left.{ }^{\circ} \mathrm{C}\right] ;[\alpha]^{22} \mathrm{D}-93$ (c $1, \mathrm{CHC1}_{3}$ ).

\subsection{General Procedure for the Silylation}

To a stirred solution of $\mathbf{1 1}$ or $\mathbf{1 2}(0.4 \mathrm{mmol})$ in $\mathrm{CH}_{2} \mathrm{Cl}_{2}(3 \mathrm{~mL})$ containing trimethylamine $(120 \mu \mathrm{L}, 0.87 \mathrm{mmol})$ and dimethylaminopyridine $(5 \mathrm{mg}, 0.04 \mathrm{mmol})$, tert-butyldimethylsilyl chloride $(125 \mu \mathrm{L}, 0.72 \mathrm{mmol})$ was added. The solution was stirred overnight at room temperature and under argon atmosphere. Then, the mixture was washed in succession with $1 \mathrm{M} \mathrm{HCl}(2 \mathrm{~mL})$, a saturated solution of $\mathrm{NaHCO}_{3}(3 \mathrm{~mL})$, water $(3 \mathrm{~mL})$ and dried over anhydrous $\mathrm{Na}_{2} \mathrm{SO}_{4}$. After evaporation under reduced pressure, the residue was purified by flash chromatography on silica gel.

Starting from $12 R$, the silyl derivative $16 R$ was obtained $(123 \mathrm{mg}, 88 \%$ yield) showing: TLC (hexane/AcOEt 7:3 v:v); $\mathrm{R}_{\mathrm{f}} 0.39 ; \mathrm{mp} 120-122^{\circ} \mathrm{C},[\alpha]^{22} \mathrm{D}-120\left(\mathrm{c} 1, \mathrm{CHC}_{3}\right)$ [lit. [52] -134 (c $\left.1, \mathrm{CHC1}_{3}\right)$ ].

Starting from $11 R$, the silyl derivative $19 R$ was obtained $(115 \mathrm{mg}, 82 \%$ yield) showing: TLC (hexane/AcOEt 7:3 v:v); $\mathrm{R}_{\mathrm{f}} 0.83 ; \mathrm{mp} 130-131^{\circ} \mathrm{C} ;[\alpha]^{22} \mathrm{D}-46\left(\mathrm{c} 0.5, \mathrm{CHC1}_{3}\right)$.

Starting from $11 S$, the silyl derivative $19 S$ was obtained $(120 \mathrm{mg}, 86 \%$ yield) showing: TLC (hexane/AcOEt 7:3 v:v); $\mathrm{R}_{\mathrm{f}} 0.89 ; \mathrm{mp} 92-93{ }^{\circ} \mathrm{C}(\mathrm{dec}) ;[\alpha]^{22} \mathrm{D}+6\left(\mathrm{c} 0.5, \mathrm{CHC1}_{3}\right)$.

\subsection{General Procedure for the Benzylation}

To a stirred solution of $\mathbf{1 1}$ or $\mathbf{1 2}(0.4 \mathrm{mmol})$ in anhydrous THF $(2 \mathrm{~mL})$ cooled to $0{ }^{\circ} \mathrm{C}$, a $60 \% \mathrm{NaH}$ dispersion $(19 \mathrm{mg}, 0.48 \mathrm{mmol}$ ) was added. Benzyl bromide ( $57 \mu \mathrm{L}, 0.48 \mathrm{mmol})$ was then added at the same temperature. The reaction mixture was allowed to warm to room temperature and then stirring was continued overnight. The mixture was then slowly poured into ice water $(2 \mathrm{~mL})$ and extracted with $\mathrm{CH}_{2} \mathrm{Cl}_{2}(3 \times 2 \mathrm{~mL})$, the organic layer was washed with water $(2 \times 3 \mathrm{~mL})$ and dried over anhydrous $\mathrm{Na}_{2} \mathrm{SO}_{4}$. The solvent was evaporated under reduced pressure and the residue was purified by flash chromatography on silica gel. 
Starting from $11 R$, the benzyl derivative $20 R$ was obtained as an oil ( $68 \mathrm{mg}, 52 \%$ yield) showing: TLC (hexane/AcOEt 7:3 v:v); $\mathrm{R}_{\mathrm{f}} 0.55 ;[\alpha]^{22} \mathrm{D}-125$ (c $0.5, \mathrm{CHC1}_{3}$ ).

Starting from 11S, the benzyl derivative $20 S$ was obtained as an oil (73 $\mathrm{mg}, 56 \%$ yield) showing: TLC (hexane/ AcOEt 7:3 v:v); $\mathrm{R}_{\mathrm{f}} 0.51 ;[\alpha]^{22} \mathrm{D}+28\left(\mathrm{c} 1, \mathrm{CHC1}_{3}\right)$.

Starting from $12 R$ in 1:1 THF/DMF mixture $(2 \mathrm{~mL})$, the only product formed and isolated by flash chromatography (hexane/AcOEt 3:7 v:v) was the (S)-3-benzyloxy-5hydroxymethyl-2(5H)-furanone (21), as a white solid (61 $\mathrm{mg}, 69 \%$ yield) showing: TLC (hexane/AcOEt 3:7 v:v); $\mathrm{R}_{\mathrm{f}} 0.37 ; \mathrm{mp} 99-102{ }^{\circ} \mathrm{C}$ [lit. [35] 99-101 $\left.{ }^{\circ} \mathrm{C}\right] ;[\alpha]^{22} \mathrm{D}+22(\mathrm{c} 1, \mathrm{MeOH})$ [lit. [35] +9.4 (c 0.85, $\mathrm{MeOH})$, [53] +11.4 (c 1, $\mathrm{MeOH})$ ]; ${ }^{13} \mathrm{C} \mathrm{NMR}\left(\mathrm{CDCl}_{3}\right)$ 63.6, 72.9, 79.3, 114.6, 127.6, 128.6, 128.7, 134.6, 146.8, 167.4 [lit. [35] ${ }^{13} \mathrm{C}$ NMR $\left(\mathrm{CDCl}_{3}\right)$ 63.6, 73.0, 79.3, 114.8, $127.7,128.6,128.7,134.8,146.9,167.4]$.

\subsection{2-O-Benzyl-3,4-O-(R)-Benzylidene-D-Ribono-1,5-Lactone (17R)}

To a solution of compound $12 R(100 \mathrm{mg}, 0.42 \mathrm{mmol})$ in dichloroethane $(14 \mathrm{~mL})$, 2-benzyloxy-1-methylpyridinium triflate $(211 \mathrm{mg}, 0.84 \mathrm{mmol}$ ) and $\mathrm{MgO}(34 \mathrm{mg}, 0.85$ $\mathrm{mmol}$ ) were added. The reaction was refluxed for $24 \mathrm{~h}$. The reaction was cooled to room temperature and filtered through Celite. The filtered element was concentered under vacuum and purified on silica gel by flash-column chromatography (hexane/AcOEt 6:4 $v: v)$ to afford compounds $\mathbf{1 7 R}(83 \mathrm{mg}, 61 \%$ yield) as white solid.

Compound 17R showed: TLC (AcOEt/hexane; $1: 1$ v:v) $\mathrm{R}_{\mathrm{f}} 0.27 ; \mathrm{mp} 172-175{ }^{\circ} \mathrm{C}$ [lit. [35] $\left.178-180{ }^{\circ} \mathrm{C}\right] ;[\alpha]^{25} \mathrm{D}-90$ (c 1.0, DMF) [lit. [35] -123.1 (c 1.17, DMF)].

\section{Conclusions}

Over the past year, COVID-19 has sparked new interests in researching $C$-nucleoside analogues, such as Remdesivir (1). A key building block of this family of compounds is the D-(+)-ribono-1,4-lactone (2), which is then reacted with the base or base-like moiety, to obtain the $C$-Nucleosides. When $C$-nucleoside analogues incorporate purines or purine-like bases, the benzylidene group is the best choice to protect the hydroxyl groups in positions 2 and 3, even though some unexpected by-products often occur due to carbohydrate ring rearrangements. Here, we present a detailed structural investigation, also using DFT computational modeling calculations, on the compounds obtained when benzylidene is used as a protective group. This study allows to clarify some aspects related to the formation of by-products and rearrangements of the carbohydrate rings. The different reactivity of lactone $\mathbf{2}$ toward either benzaldehyde or benzaldehyde dimethyl acetal under different reaction conditions is associated with relatively minor changes in structure. Structural assignments for O-benzylidene-D-ribono-1,4-lactones were achieved using conventional NMR/n.O.e. techniques. In a general sense, the observed correlation between $\mathrm{H}-3$ and H-4 is characteristic for D-ribono-1,5-lactones, but not for D-ribono-1,4-lactones. In addition, significant spin-spin interactions between $\mathrm{H}-4$ and $\mathrm{H}-5$ are present in D-ribono-1,4-lactones. The trends featured by D-ribono-1,4-lactones can be helpful resources to account for their physicochemical characterization in a simple and reliable way. The study herein presented, with the unequivocal identification of the NMR signals characteristics of the five-membered or six-membered carbohydrate rings, allows to identify which synthetic strategies lead to the undesired six-membered ring formation.

Supplementary Materials: The following are available online. ${ }^{1} \mathrm{H}$ and ${ }^{13} \mathrm{C}-\mathrm{NMR}$ spectra of compounds 11R, 11S, 12R, 15R, 16R, 17R, 18R, 18S, 19R, 19S, 20R, 20S; Energies, relative energies and Boltzmann population distribution at $298 \mathrm{~K}$ of conformers of the compounds $12 R$ (Table S1) and $12 \mathrm{~S}$ (Table S2), calculated using B3LYP/6-31G* and SM8 solution model for DMSO; energies, relative energies and Boltzmann population distribution at $298 \mathrm{~K}$ of conformers of the compounds $11 \mathrm{R}$ (Table S3) and 11S (Table S4), calculated using B3LYP / 6-31G* and SM8 solution model for CHCl3.

Author Contributions: Conceptualization, P.C. and P.A.; data curation, P.C., S.C., R.O., P.A. and P.R.; formal analysis, A.M., P.C., S.C. and P.R.; funding acquisition, P.C. and P.R.; investigation, P.C., S.C., R.O., P.A. and P.R.; project administration, P.C. and P.R.; writing-original draft preparation, P.C., 
S.C., R.O., P.A. and P.R.; writing-review and editing, P.C., S.C., R.O., P.A. and P.R. All authors have read and agreed to the published version of the manuscript.

Funding: This research was funded by the Università degli Studi di Milano, Finanziamento di Ateneo-Linea 3-Bando SEED-PSR 2019 funding to PC and PR.

Institutional Review Board Statement: Not applicable.

Informed Consent Statement: Not applicable.

Data Availability Statement: The data presented in this study are available within the article and in the Supplementary Materials.

Acknowledgments: The authors are thankful to the Università degli Studi di Milano for financial support.

Conflicts of Interest: The authors declare no conflict of interest.

Sample Availability: Samples of all compounds are not available from the authors.

\section{References}

1. Lin, X.; Liang, C.; Zou, L.; Yin, Y.; Wang, J.; Chen, D.; Lan, W. Advance of structural modification of nucleosides scaffold. Eur. J. Med. Chem. 2021, 214, 113233. [CrossRef] [PubMed]

2. Zhu, Y.; Li, J.; Pang, Z. Recent insights for the emerging COVID-19: Drug discovery, therapeutic options and vaccine development. Asian J. Pharm. Sci. 2021, 16, 4-23. [CrossRef]

3. Debing, Y.; Emerson, S.U.; Wang, Y.; Pan, Q.; Balzarini, J.; Dallmeier, K.; Neyts, J. Ribavirin inhibits in vitro hepatitis E virus replication through depletion of cellular GTP pools and is moderately synergistic with alpha interferon. Antimicrob. Agents Chemother. 2014, 58, 267-273. [CrossRef]

4. Lo, M.K.; Feldmann, F.; Gary, J.M.; Jordan, R.; Bannister, R.; Cronin, J.; Patel, N.R.; Klena, J.D.; Nichol, S.T.; Cihlar, T.; et al. Remdesivir (GS-5734) protects African green monkeys from Nipah virus challenge. Sci. Transl. Med. 2019, 11, 494. [CrossRef]

5. Tchesnokov, E.P.; Feng, J.Y.; Porter, D.P.; Götte, M. Mechanism of Inhibition of Ebola Virus RNA-Dependent RNA Polymerase by Remdesivir. Viruses 2019, 11, 326. [CrossRef]

6. Sheahan, T.P.; Sims, A.C.; Leist, S.R.; Schäfer, A.; Won, J.; Brown, A.J.; Montgomery, S.A.; Hogg, A.; Babusis, D.; Clarke, M.O.; et al. Comparative therapeutic efficacy of remdesivir and combination lopinavir, ritonavir, and interferon beta against MERS-CoV. Nat. Commun. 2020, 11, 222. [CrossRef]

7. Wang, M.; Cao, R.; Zhang, L.; Yang, X.; Liu, J.; Xu, M.; Shi, Z.; Hu, Z.; Zhong, W.; Xiao, G. Remdesivir and chloroquine effectively inhibit the recently emerged novel coronavirus (2019-nCoV) in vitro. Cell Res. 2020, 30, 269-271. [CrossRef]

8. Warren, T.K.; Jordan, R.; Lo, M.K.; Ray, A.S.; Mackman, R.L.; Soloveva, V.; Siegel, D.; Perron, M.; Bannister, R.; Hui, H.C.; et al. Therapeutic efficacy of the small molecule GS-5734 against Ebola virus in rhesus monkeys. Nature 2016, 531, 381-385. [CrossRef]

9. Stambaský, J.; Hocek, M.; Kocovský, P. C-nucleosides: Synthetic strategies and biological applications. Chem. Rev. 2009, 109, 6729-6764. [CrossRef]

10. Siegel, D.; Hui, H.C.; Doerffler, E.; Clarke, M.O.; Chun, K.; Zhang, L.; Neville, S.; Carra, E.; Lew, W.; Ross, B.; et al. Discovery and Synthesis of a Phosphoramidate Prodrug of a Pyrrolo2,1-ftriazin-4-amino Adenine C-Nucleoside (GS-5734) for the Treatment of Ebola and Emerging Viruses. J. Med. Chem. 2017, 60, 1648-1661. [CrossRef]

11. Cho, A.; Saunders, O.L.; Butler, T.; Zhang, L.; Xu, J.; Vela, J.E.; Feng, J.Y.; Ray, A.S.; Kim, C.U. Synthesis and antiviral activity of a series of 1'-substituted 4-aza-7,9-dideazaadenosine C-nucleosides. Bioorg. Med. Chem. Lett. 2012, 22, 2705-2707. [CrossRef] [PubMed]

12. Metobo, S.E.; Xu, J.; Saunders, O.L.; Butler, T.; Aktoudianakis, E.; Cho, A.; Kim, C.U. Practical synthesis of $1^{\prime}$-substituted Tubercidin C-nucleoside analogs. Tetrahedron Lett. 2012, 53, 484-486. [CrossRef]

13. Hamon, N.; Uttaro, J.-P.; Mathé, C.; Périgaud, C. Synthesis of the natural enantiomer of neplanocin B. Bioorg. Chem. 2010, 38, 275-278. [CrossRef] [PubMed]

14. Karlubíková, O.; Palík, M.; Lásiková, A.; Gracza, T. An Efficient Total Synthesis of (+)-Varitriol from d-Ribonolactone. Synthesis 2010, 2010, 3449-3452. [CrossRef]

15. Kubelka, T.; Slavětínská, L.; Hocek, M. Synthesis of Substituted Benzyl Homo-C-Ribonucleosides and -Nucleotides as Carba Analogues of Phosphoribosylanthranilate. Eur. J. Org. Chem. 2012, 2012, 4969-4981. [CrossRef]

16. Stefko, M.; Slavetínská, L.; Klepetárová, B.; Hocek, M. A general and efficient synthesis of pyridin-2-yl C-ribonucleosides bearing diverse alkyl, aryl, amino, and carbamoyl groups in position 6. J. Org. Chem. 2010, 75, 442-449. [CrossRef]

17. Ciuffreda, P.; Buzzi, B.; Alessandrini, L.; Santaniello, E. Activity of Adenosine Deaminase (ADA) and Adenylate Deaminase (AMPDA) Towards 6-Chloropurine Nucleosides Modified in the Ribose Moiety. Eur. J. Org. Chem. 2004, $2004,4405-4409$. [CrossRef] 
18. Ciuffreda, P.; Alessandrini, L.; Santaniello, E. $2^{\prime}, 3^{\prime}$-isopropylidene group, a molecular scaffold to study the activity of adenosine and adenylate deaminase on adenosine analogues modified in the ribose moiety. Nucleosides Nucleotides Nucleic Acids 2007, 26, 1311-1313. [CrossRef] [PubMed]

19. Wuts, P.G.M.; Greene, T.W. Chapter 2: Protection on 1,2 and 1,3 diols. In Greene's Protective Groups in Organic Synthesis, 4th ed.; Wiley: Hoboken, NJ, USA, 2006; ISBN 978-0-470-05348-5.

20. Cappellacci, L.; Barboni, G.; Palmieri, M.; Pasqualini, M.; Grifantini, M.; Costa, B.; Martini, C.; Franchetti, P. Ribose-modified nucleosides as ligands for adenosine receptors: Synthesis, conformational analysis, and biological evaluation of $1^{\prime}-\mathrm{C}-\mathrm{methyl}$ adenosine analogues. J. Med. Chem. 2002, 45, 1196-1202. [CrossRef] [PubMed]

21. Cappellacci, L.; Franchetti, P.; Vita, P.; Petrelli, R.; Lavecchia, A.; Jayaram, H.N.; Saiko, P.; Graser, G.; Szekeres, T.; Grifantini, M. Ribose-modified purine nucleosides as ribonucleotide reductase inhibitors. Synthesis, antitumor activity, and molecular modeling of N6-substituted 3'-C-methyladenosine derivatives. J. Med. Chem. 2008, 51, 4260-4269. [CrossRef]

22. Franchetti, P.; Cappellacci, L.; Pasqualini, M.; Petrelli, R.; Vita, P.; Jayaram, H.N.; Horvath, Z.; Szekeres, T.; Grifantini, M. Antitumor activity of C-methyl-beta-D-ribofuranosyladenine nucleoside ribonucleotide reductase inhibitors. J. Med. Chem. 2005, 48, 4983-4989. [CrossRef]

23. Franchetti, P.; Cappellacci, L.; Vita, P.; Petrelli, R.; Lavecchia, A.; Kachler, S.; Klotz, K.-N.; Marabese, I.; Luongo, L.; Maione, S.; et al. N6-Cycloalkyl- and N6-bicycloalkyl-C5'(C2')-modified adenosine derivatives as high-affinity and selective agonists at the human A1 adenosine receptor with antinociceptive effects in mice. J. Med. Chem. 2009, 52, 2393-2406. [CrossRef] [PubMed]

24. Clode, D.M. Carbohydrate cyclic acetal formation and migration. Chem. Rev. 1979, 79, 491-513. [CrossRef]

25. Vidal, S. Protecting Groups: Strategies and Applications in Carbohydrate Chemistry; Wiley: Weinheim, Germany, 2019; ISBN 978-3-52734010-1.

26. Brady, R.F. Cyclic Acetals of Ketoses. In Advances in Carbohydrate Chemistry and Biochemistry; Elsevier: Amsterdam, The Netherlands, 1971; pp. 197-278. ISBN 9780120072262.

27. Pétursson, S. Protecting Groups in Carbohydrate Chemistry. J. Chem. Educ. 1997, 74, 1297. [CrossRef]

28. Rauter, A.P.; Ramôa-Ribeiro, F.; Fernandes, A.C.; Figueiredo, J. A new method of acetonation with the zeolite HY as catalyst. Synthesis of O-Isopropylidene sugar derivatives. Tetrahedron 1995, 51, 6529-6540. [CrossRef]

29. Han, S.-Y.; Joullié, M.M.; Fokin, V.V.; Petasis, N.A. Spectroscopic, crystallographic and computational studies of the formation and isomerization of cyclic acetals and ketals of pentonolactones. Tetrahedron Asymmetry 1994, 5, 2535-2562. [CrossRef]

30. Han, S.-Y.; Joullié, M.M.; Petasis, N.A.; Bigorra, J.; Corbera, J.; Font, J.; Ortuño, R.M. Investigations of the formation of cyclic acetal and ketal derivatives of D-ribono-1,4-lactone and 2-deoxy-D-ribono-1,4-lactone. Tetrahedron 1993, 49, 349-362. [CrossRef]

31. Clode, D.M. The acid-catalyzed rearrangement of methyl 3,4- O -benzylidene- $\beta$ - D -ribopyranoside. Can. J. Chem. 1977, 55, 4071-4077. [CrossRef]

32. Zinner, H.; Voigt, H.; Voigt, J. Benzyliden-verbindungen der pentonsäuren und pentonsäure-lactone. Carbohydr. Res. 1968, 7, 38-55. [CrossRef]

33. Baggett, N.; Buchanan, J.G.; Fatah, M.Y.; Lachut, C.H.; McCullough, K.J.; Webber, J.M. Benzylidene acetals of the D-ribonolactones: A structural reassessment. J. Chem. Soc. Chem. Commun. 1985, 84, 1826-1827. [CrossRef]

34. Bigorra, J.; Font, J.; de Echagüen, C.O.; Ortuño, R.M. Synthetic approaches to either homochiral or achiral derivatives of 3-hydroxy-2(5H)-furanone (isotetronic acid). Tetrahedron 1993, 49, 6717-6728. [CrossRef]

35. Poon, K.W.; House, S.E.; Dudley, G.B. A Bench-Stable Organic Salt for the Benzylation of Alcohols. Synlett 2005, 20, 3142-3144. [CrossRef]

36. Poon, K.W.C.; Dudley, G.B. Mix-and-heat benzylation of alcohols using a bench-stable pyridinium salt. J. Org. Chem. 2006, 71, 3923-3927. [CrossRef]

37. Casati, S.; Manzocchi, A.; Ottria, R.; Ciuffreda, P. 1H, 13C and 15N NMR assignments for N6-isopentenyladenosine/inosine analogues. Magn. Reson. Chem. 2010, 48, 745-748. [CrossRef] [PubMed]

38. Vago, R.; Bettiga, A.; Salonia, A.; Ciuffreda, P.; Ottria, R. Development of new inhibitors for N-acylethanolamine-hydrolyzing acid amidase as promising tool against bladder cancer. Bioorg. Med. Chem. 2017, 25, 1242-1249. [CrossRef]

39. Lauria, S.; Perrotta, C.; Casati, S.; Di Renzo, I.; Ottria, R.; Eberini, I.; Palazzolo, L.; Parravicini, C.; Ciuffreda, P. Design, synthesis, molecular modelling and in vitro cytotoxicity analysis of novel carbamate derivatives as inhibitors of Monoacylglycerol lipase. Bioorg. Med. Chem. 2018, 26, 2561-2572. [CrossRef]

40. Kiss, R.; Fizil, Á.; Szántay, C. What NMR can do in the biopharmaceutical industry. J. Pharm. Biomed. Anal. 2018, 147, 367-377. [CrossRef]

41. Ottria, R.; Casati, S.; Ciuffreda, P. (1)H, (13)C and (15)N NMR assignments for N- and O-acylethanolamines, important family of naturally occurring bioactive lipid mediators. Magn. Reson. Chem. 2012, 50, 823-828. [CrossRef] [PubMed]

42. Haasnoot, C.; de Leeuw, F.; Altona, C. The relationship between proton-proton NMR coupling constants and substituent electronegativities-I. Tetrahedron 1980, 36, 2783-2792. [CrossRef]

43. Baird, P.D.; Dho, J.C.; Fleet, G.W.J.; Peach, J.M.; Prout, K.; Smith, P.W. Synthesis of (2R,3S,4R)-3,4-dihydroxyproline from $D$-ribonolactone; an approach to the synthesis of polyfunctionalised $D$-amino acids from sugar lactones. X-Ray molecular structures of 2-azido-3,4-O-(R)-benzylidene-2-deoxy-D-ribono-1,5-lactone, 2-azido-2-deoxy- $D$-ribono-1,4-lactone, and (2R,3S,3R)3,4-dihydroxyproline. J. Chem. Soc. Perkin Trans. 1 1987, 1785. [CrossRef] 
44. Grindley, T.; Gulasekharam, V. Benzylidene acetal structural elucidation by N.M.R. Spectroscopy: Application of carbon-13. N.M.R.-Spectral parameters. Carbohydr. Res. 1979, 74, 7-30. [CrossRef]

45. Cremer, D.; Pople, J.A. General definition of ring puckering coordinates. J. Am. Chem. Soc. 1975, 97, 1354-1358. [CrossRef]

46. Cremer, D. On the correct usage of the Cremer-Pople puckering parameters as quantitative descriptors of ring shapes-A reply to recent criticism by Petit, Dillen and Geise. Acta Cryst. B Struct. Sci. 1984, 40, 498-500. [CrossRef]

47. Casati, S.; Manzocchi, A.; Ottria, R.; Ciuffreda, P. 1H, 13C and 15N NMR spectral assignments of adenosine derivatives with different amino substituents at C6-position. Magn. Reson. Chem. 2011, 49, 279-283. [CrossRef] [PubMed]

48. Casati, S.; Ottria, R.; Ciuffreda, P. 17alpha- and 17beta-boldenone 17-glucuronides: Synthesis and complete characterization by 1H and 13C NMR. Steroids 2009, 74, 250-255. [CrossRef]

49. Ciuffreda, P.; Casati, S.; Manzocchi, A. Complete 1H and 13C NMR spectral assignment of 17-hydroxy epimeric sterols with planar A or A and B rings. Magn. Reson. Chem. 2004, 42, 360-363. [CrossRef]

50. Ciuffreda, P.; Casati, S.; de Mieri, M.; Ferraboschi, P. Corticosteroids 21-glucuronides: Synthesis and complete characterization by (1)H and (13)C NMR. Steroids 2009, 74, 870-875. [CrossRef] [PubMed]

51. Marenich, A.V.; Olson, R.M.; Kelly, C.P.; Cramer, C.J.; Truhlar, D.G. Self-Consistent Reaction Field Model for Aqueous and Nonaqueous Solutions Based on Accurate Polarized Partial Charges. J. Chem. Theory Comput. 2007, 3, 2011-2033. [CrossRef]

52. Lefeber, D.J.; Steunenberg, P.; Vliegenthart, J.F.; Kamerling, J.P. Synthesis of differentially protected ribitol derivatives from 3,4-O-benzylidene-d-ribono-1,5-lactone. Tetrahedron Asymmetry 2005, 16, 507-511. [CrossRef]

53. Weidmann, H.; Timpe, W.; Wolf, N. Reaktionen von kohlenhydratderivaten mit komplexen metallhydriden. Carbohydr. Res. 1972, 25, 67-70. [CrossRef] 